\title{
KOMUNIKASI VERBAL ABUSE ORANG TUA PADA REMAJA
}

(Studi Deskriptif Konsep Diri Remaja Di Kecamatan Kerumutan Kabupaten Pelalawan)

\author{
Hevi Susanti, Nujanah \\ Fakultas Ilmu Sosial dan Ilmu Politik Universitas Riau \\ e-mail: hevisusanti@gmail.com
}

\begin{abstract}
The phenomenon that lately occurs and entrenched in the environment of Indonesian society in general and in particular in the District of Kerumutan, Pelalawan Regency, which considers that talking harshly, berating, yelling, scolding, threatening to children is normal. But parents should be able to give good examples to children by using language or words that are good and right. This condition can occur where parents do not really understand and do not know that the verbal ability possessed by parents in communicating with children will be directly absorbed by children and form a sustainable behavior.

Results Self-concept owned by teenagers in Kec. Kerumutan Kab. Pelalawan is influenced by significant others. Where, adolescent self-concept in Kec. Kerumutan Kab. Pelalawan is a negative selfconcept that is the type of social comparison and Biased scannin. The negative self-concept of social comparision type is of the view that it is indeed like what is said by others so that the view of itself really looks irregular because the self-concept formed is influenced by others. While the negative self-concept is Biased scannin type. Shown from the attitude of adolescents that he tends to feel unliked by his parents and feel unnoticed. Reflected Appraisal states that a person's self-concept will be formed if he gets an award from someone else. Where, the giver of appreciation and the amount of appreciation received by a person will determine the degree of self-concept that is formed. Appreciation from people who are considered important to someone (significant others such as: parents, friends, relatives, etc.) also provide a very big influence on the development of self-concept.
\end{abstract}

Keywords: Adolescents, Self-concept, Verbal Abuse Communication

\section{Abstrak}

Fenomena yang akhir-akhir ini terjadi dan membudaya di lingkungan masyarakat indonesia umumnya dan khususnya di Kecamatan Kerumutan Kabupaten Pelalawan dimana menganggap hal bicara kasar, mencaci, membentak, memarahi, mengancam pada anak merupakan hal wajar. Namun seharusnya orang tua dapat memberikan contoh yang baik kepada anak dengan menggunakan bahasa atau kata-kata yang baik dan benar. Kondisi ini dapat terjadi yang mana orang tua tidak begitu paham dan tidak mengetahui bahwa kemampuan verbal yang dimiliki oleh orang tua dalam berkomunikasi dengan anak akan langsung diserap oleh anak dan membentuk suatu perilaku berkelanjutan.

Hasil Konsep diri yang dimiliki remaja di Kec. Kerumutan Kab.Pelalawan dipengaruhi oleh significant others. Dimana, konsep diri remaja di Kec. Kerumutan Kab. Pelalawan adalah konsep diri bertipe negatif yakni tipe social comparasion dan Biased scannin. Konsep diri negatif tipe social comparision adalah berpandangan bahwa dirinya memang seperti apa yang dikatakan oleh orang lain sehingga pandangan mengenai dirinya sendiri benar-benar terlihat tidak teratur dikarenakan konsep diri yang terbentuk di pengaruhi oleh orang lain. Sedangkan konsep diri negatif tipe Biased scannin. Ditunjukkan dari sikap remaja yang ia cenderung merasa tidak disenangi oleh orang tuanya dan merasa tidak diperhatikan. Reflected Appraisal menyatakan bahwa konsep diri seseorang akan terbentuk jika ia mendapatkan penghargaan dari orang lain. Dimana, pemberi penghargaan dan besarnya penghargaan yang diterima seseorang tersebut akan menentukan derajat konsep diri yang terbentuk. Penghargaan dari orang-orang yang dianggap penting bagi seseorang (significant others seperti: orang tua, teman, 
saudara, dan sebagainya) juga memberikan pengaruh yang sangat besar terhadap pengembangan konsep diri.

Kata Kunci : Remaja, Konsep diri, Komunikasi Verbal Abuse

\section{PENDAHULUAN}

Berbicara kasar, mencaci, membentak, memarahi dan mengancam pada anak merupakan fenomena yang akhir-akhir ini terjadi dan telah membudaya di lingkungan masyarakat indonesia khususnya di Kecamatan Kerumutan Kabupaten Pelalawan. Dimana perilaku tersebut di anggap wajar dan biasa yang dilakukan orang tua untuk memberikan contoh kepada anak dengan menggunakan bahasa atau kata-kata yang tidak baik agar anak patuh dan nurut. Kondisi ini dapat terjadi dimana orang tua tidak begitu paham dan tidak mengetahui bahwa kemampuan verbal yang dimiliki oleh orang tua dalam berkomunikasi kepada anak akan langsung diserap oleh anak dan fatalnya lagi, perilaku yang dilakukan orang tua tersebut akan membentuk suatu perilaku yang berkelanjutan nantinya pada anak.

Banyak sekali bentuk-bentuk dari jenis perilaku komunikasi yang ditafsirkan sebagai pelecehan verbal atau dikenal dengan verbal abuse. Kekerasan verbal atau verbal abuse merupakan bagian dari tindakan komunikasi dengan mengunakan ucapan atau kata-kata kasar ataupun kekerasan secara verbal yang dilakukan oleh orang tua pada anak (Charles, 1998). Lawson (2006 dalam Rakhmat, 2007) mengelompokkan kekerasan pada anak, diantaranya yaitu verbal abuse, physical abuse dan sexual abuse. Sehingga apabila anak mendapati tindakan kekerasan secara verbal secara terus-menerus maka akan dipastikan anak tersebut akan mengalami perubahan pada perilaku dan dapat saja menghacurkan konsep diri dari sang anak.

Berdasarkan fenomena verbal abuse yang terjadi pada remaja saat ini, memberikan sebuah dampak negatif terhadap pembentukan kepribadian pada remaja. Konsep diri memiliki peran yang cukup penting dalam penentuan sikap, perilaku dan reaksi anak terhadap orang lain dan begitupun dilingkungan sekitarnya. Banyak anak yang mengembangkan konsep diri yang cenderung negatif. Disnilah harusnya peran orang tua untuk bertanggung jawab dalam membimbing mereka, namun orang tua tidak menyadari peran tersebut.

Harian Tempo menyebutkan bahwa masih tingginya tingkat kekerasan terhadap anak di Indonesia yang masih tergolong tinggi. Banyak dari pelaku kekerasan terhadap anak ini justru adalah orang tua dari anak itu sendiri. Menurut KPAI (Komisi Perlindungan Anak Indonesia) setiap tahun anggka kekerasan terhadap anak justru mencapai 3700 dan rata-rata terjadi 15 kasus setiap harinya. (Tempo, 26 April 2016). Sebanyak 60\% merupakan korban kekerasan ringan, berupa kekersan secara verbal atau caci maki, sedangkan 40\% sisanya mengalami kekerasan fisik hingga seksual (Solihin, 2005).

Kekerasan verbal abuse yang dilakukan oleh orang tua lebih berpengaruh terhadap masalah psikososial pada anak yaitu kesulitan-kesulitan dalam proses pencarian identitas, dari pada orang tua yang melakukan kekerasan secara fisik. Ketika anak mulai melakukan pemberontakan, orang tua akan memarahi anaknya, mencemooh dan memberikan kata-kata kasar kepada anaknya sebagai bentuk hukuman atas kesalahan yang dibuat oleh anaknya.

Menurut Lindenfield (1997) ketika seseorang mengalami rasa tidak aman atau mengalami ketakutan, maka hal tersebut akan menjadi musuh terbesar bagi tumbuhnya rasa percaya diri. Menurut Puspasari (2007) persepsi yang buruk terhadap diri sendiri dan harga diri yang rendah akan menumbuhkan kepercayaan diri yang rendah.

Dalam penelitian Words That Hurt: A Qualitative Study of Parental Verbal Abuse in the Philippines oleh Jennifer (M. I.) Loh, Flora Calleja, dan Simon Lloyd D. Restubog, yang mana dalam hasil 
penelitiannya, menyebutkan bahwa perilaku verbal orang tua pada anak di philipina memberikan dampak lain yakni mengalami kurangnya rasa percaya diri, anak menarik diri dari lingkungan luar dan merasa tidak layak hidup.

Kekerasan terhadap anak ini dapat menimbulkan rasa sakit baik secara fisik maupun psikis sehingga lambat laun anak akan kehilangan rasa percaya diri. Rasa percaya diri yang dimiliki anak dapat membantu anak dalam mengenal dirinya sendiri. Jika rasa percaya diri anak rendah maka anak akan sulit mengembangkan kepercayaan pada orang lain, merasa tidak aman, dan anak juga akan menilai dirinya tidak berguna dan bahkan dapat mengubah perilaku anak menjadi agresif.

Tetapi jika kepercayaan diri anak tinggi anak akan lebih mudah bergaul dengan orang lain, dapat mengembangkan kepercayaan pada orang lain dan merasa dibutuhkan dan berguna baik pada diri sendiri maupun orang lain. Selain itu jika perilaku kekerasan ini terus menerus dialami oleh sang anak maka bukan tidak mungkin akan termanifestasi dalam beberapa bentuk, seperti kurangnya rasa percaya diri, kesulitan membina persahabatan, perilaku merusak, menarik diri dari lingkungan, penyalahgunaan obat dan alkohol, ataupun kecenderungan bunuh diri.

Dikecamatan kerumutan menurut data sekolah menengah pertama pada tahun 2016 nilai rata-rata akademis siswa-siswi berada pada persentase baik di atas 78\% pada angka rata-rata 89,7. Pada tahun 2017 presentase menurun pada $74 \%$ pada angka rata-rata $87,3 \%$ dan begitu pula data presentase sekolah menengah atas ditahun 2016 masih tercatat dengan rata-rata nilai baik di atas $75 \%$ pada angka rata-rata 87,7\% dan menurun pada tahun 2017 pada 70\% pada rata-rata angka 80,7\%. (Sumber data SMP Kerumutan, data SMA Kerumutan 2018).

\section{METODE}

Penelitian ini menggunakan metode penelitian kualitatif, dengan informan adalah remaja yang pernah mendapati perlakuan verval abuse dari orang tua, dengan rentang usia 12-17 tahun. Rentang usia tersebut digunakan atas pertimbangan faktor kepribadian yang di ukur. Peneliti telah memilih 3 orang informan yang dianggap telah memenuhi kriteria yang dibutuhkan untuk menjadi informan yang sesuai dengan pemilihan informan dalam penelitian ini. Peneliti juga telah menentukan informan pendukung yaitu 9 orang significant others atau orang-orang yang dianggap penting bagi remaja yang mengalami perlakuan komunikasi verbal abuse orang tua, seperti guru, teman, dan lainnya.

Adapun kriteria informan dalam penelitian ini sebagai berikut:

a. Informan haruslah remaja yang berada dalam rentang usia 12 sampai 17 tahun.

b. Informan harus mengalami langsung situasi atau kejadian yang berkaitan dengan objek penelitian, yang dalam penelitian ini ialah remaja yang mengalami perilaku komunikasi verbal abuse dari orang tua. Tujuannya untuk mendapatkan deskripsi dari sudut pandang orang pertama sehingga dapat mendukung otensitas penelitian.

c. Informan dalam penelitian ini ialah remaja yang bertimpat tinggal di Kec. Kerumutan Kab. Pelalawan.

\section{HASIL DAN PEMBAHASAN}

Komunikasi verbal abuse memberikan dampak pada perilaku negatif pada remaja, dengan maksud atau niat untuk menyakiti orang lain serta dapat menghancurkan konsep diri seorang anak atau remaja sehingga menjadi kurang percaya diri, (Infant \& Rancer, 1996; Rollof \& Greenburg, 1979). Konsep diri memiliki peran yang cukup penting dalam penentuan sikap, perilaku dan reaksi anak 
terhadap orang lain dan lingkungan sekitarnya. Banyak anak yang mengembangkan konsep diri yang cenderung negatif. Fenomena tersebutlah yang akhir-akhir ini terjadi dan membudaya di lingkungan masyarakat khususnya di Kecamatan Kerumutan Kabupaten Pelalawan, dimana menganggap hal bicara kasar, mencaci, membentak, memarahi, mengancam pada anak merupakan hal wajar.

\section{Kronologi Terjadinya Tindakan Verbal Abuse Orang Tua Kepada Anak}

Subjek DD menjadi korban verbal abuse sejak duduk di sekolah dasar sampai sekarang. Tindakan verbal abuse yang diterimanya seperti menghardik dan menghakimi dengan perkataan yang tidak pantas. Pernyataan itu pun dibenarkan oleh tetangga DD, bahwa DD sering mendapatkan tindakan kekerasan secara verbal dari orang tuanya seperti yang telah diceritakan DD. Begitupun pada subjek SU. Subjek SU telah mendapatkan tindakan kekerasan secara verbal dari orang tua sejak di bangku sekolah dasar, dan semakin menjadi-jadi saat berada di bangku SMA sampai sekarang. Serta informan AK mendapatkan tindakan kekerasan verbal abuse dari SMP. Setelah ayahnya meninggal, Ibunya menjadi lebih sering memberikan tindakan verbal berupa membentak, melebel dan memaki. Tidak peduli mau di rumah atau di tempat umum.

Dari ketiga informan yaitu DD, SU, AK mendapatkan tindakan komunikasi verbal abuse sejak mereka duduk di bangku SD dan SMP. Alasan yang melatarbelakangi ketiga informan yang menjadi sasaran korban verbal abuse dari orang tua dapat diketahui sebagai berikut. Pada subjek DD, dirinya mendapatkan tindakan verbal abuse karena merasa bahwa dirinya memang agak sedikit lamban dalam mengerjakan sesuatu sehingga orang tuanya tidak sabaran dan memarahinya dengan nada yang tinggi. Selain itu, DD juga merasa karena dirinya banyak menghabiskan waktu sendiri serta karena sifatnya yang pendiam sehingga tidak banyak teman yang dekat dengannya.

Sedangkan informan SU sering mendapatkan komunikasi verbal abuse karena sering tidak mengindahkan permintan ibunya. Sedangkan SU asik dengan bermain games di kamarnya. Begitu juga dengan AK, hal yang hampir sama menjadi alasan AK mendapatkan tindakan komunikasi verbal abuse.

\section{Konsep Diri Remaja Korban verbal abuse orang tua}

Konsep diri remaja pada korban verbal abuse orang tua di Kecamatan Kerumutan Kabupaten Pelalawan terdapat tiga aspek dimensi internal konsep diri terdiri dari identitas diri, perilaku diri, dan penerimaan diri. Dari ketiga dimensi internal tersebut dikaitkan dengan dimensi eksternal yang terdiri dari fisik, moral-etik, pribadi, keluarga, dan sosial. Dalam penelitian ini, 3 aspek konsep diri tersebut akan dijabarkan pada masing-masing subjek.

\section{Subjek DD}

Subjek DD menggambarkan identitas moral etiknya dengan baik. Subjek DD mengaku bahwa dirinya selalu melaksanakan sholat 5 waktu meskipun tidak selalu dilaksanakan berjamaah di masjid. Dalam kegiatannya di sekolah pun subjek selalu mematuhi tatatertib yang berlaku di sekolah. DD lebih sering memendam segala perasaan dan masalah yang sedang terjadi padanya teman-temannya. Subjek DD menjelaskan dengan baik seperti apa kondisi keluarganya. Namun saat menceritakan hubungannya dengan kedua orang tuanya, DD tidak banyak menjelaskan hubungannya dengan orang tuanya. Sehingga subjek DD memperlihatkan hubungan yang tidak begitu dekat dengan kedua orang tuanya. Terkait dengan tindakan komunikasi verbal abuse yang dialami DD, DD mengaku jika gurunya tidak mengetahuinya termasuk teman-teman di sekolahnya. Keyakinan tersebut menunjukkan bahwa DD merasa tidak disenangi orang lain dan merasa kurang diperhatikan. Oleh karena itu DD tidak dapat melahirkan kehangatan dan keakraban dan cenderung lebih banyak diam degan orang lain. Sehingga hal tersebut merupakan dasar dari terbentuknya konsep diri negatif pada DD. Pernyataan DD dibenarkan dan didukung oleh tetanganya Ibu ST mengenai konsep diri negatif yang dimilikinya. 


\section{Subjek SU}

Informan SU mengaku dirinya jarang menunaikan ibadah tsholat wajib 5 waktu dan hanya sholat ketika dirinya berada di sekolah, namun ketika di rumah, ibunya tidak pernah mengingatkan untuk menunaikan ibadah sholat. Saat Informan SU menjelasan mengenai keluarganya, ia sangat menggebugebu dan terlihat ada perasaan kesal dan marah di dalam hatinya. SU sosok yang tidak begitu dekat dengan kedua orang tuanya. Informan SU sendiri tidak memiliki banyak teman dekat dan hanya sebatas teman sepermainannya di rumah. SU terlihat berbeda ketika dirumah dan menjadi anak yang pendiam dan penurut serta terkadang sesekali orang tuanya menyegahnya dengan perkataan yang tidak pantas dan suka berteriak ketika memanggil SU. Ibuk RY, tetangganya kerap kali mendapati tindakan verbal abuse dari orang tuanya. Terkait tindakan komunikasi verbal abuse, SU,mengaku jika gurunya tidak ada yang mengetahui termasuk teman-teman di sekolahnya. Hal ini pun di benarkan oleh Pernyataan yang diberikan oleh tetanganya Ibuk RY yang mengenalnya dari sejak kecil dan semakin memperkuat mengenai konsep diri negatif yang dimilikinya.

\section{Subjek AK}

Informan AK selalu melakukan sholat 5 waktu dan berbuat baik di rumah, rajin membantu ibunya, mengerjakan apa yang diperintahkan orantuanya. Apa saja ia akan perbuat karena ingin menjadi anak yang di inginkan ibunya. Lain halnya jika sudah di luar rumah, ia menjadi anak yang bebas, apa saja yang ia inginkan. Di sekolah ia menjadi anak yang suka menjaili teman-teman sekolahnya dan juga membuat anak-anak perempuan tidak menyukainya karena ia menganggap perempuan itu sangat menyebalkan, sehingga anak permpuan di kelasnya sering ia buat menangis. Hal ini di dukung oleh pernyataan guru wali kelas AK yaitu ibu AZ. AK mempunyai banyak teman, yang mempunyai sikap yang tidak jauh berbeda dari AK. AK disekolah adalah anak anak yang pintar,ia selalu masuk dalam 10 besar tapi saat ini sudah tidak lagi masuk 10 besar saat ini ia berubah ia jadi suka rusuh dan suka menjaili teman-teman sekolahnya. Terkait dengan tindakan komunikasi verbal abuse yang di alaminya, ada beberapa temannya yang sering datang ke rumah dan mengetahui bahwa ia sering mendapatkan tidakan tersebut dimana ibu dari AK biasa memarahi atau memperlakukan AK seperti bukan anaknya.

Disisi lain, AK mengaku dirinya memang tidak memiliki semangat belajar. Setelah ayahnya meninggal ia seperti kehilangan panutan karena ia sangat dekat dengan ayahnya. Menurutnya ayah adalah penyemangat hidupnya. Ibunya menganggap apapun yang dilakukannya selalu salah dimata ibunya. Di sekolah semua guru mengenalnya karena prilakunya yang berubah, dulu AK anak yang baik tidak sperti saat ini yang menunjukkan sikap dan tingkah laku yang buruknya di kelasnya. AK menyadari apa yang ia lakukan di kelas tidak baik, namun ia tetap melakukannya. AK mengaku dengan hal seperti itu ia merasa senang dan membuatnya bahagia sehingga ia selalu melakukannya lagi dan lagi.

Keyakinan tersebut menunjukkan bahwa ia merasa tidak disenangi orang lain. Ia merasa kurang diperhatikan. Karena itulah sehingga ia cenderung tidak dapat menciptakan kehangatan dan keakraban dengan orang lain. Hal tersebut merupakan dasar dari konsep diri negatif. Pernyataan ini dibenarkan oleh tetanganya Ibuk WT yang mengenalnya dari kecil dan semakin mendukung mengenai konsep diri negatif yang dimilikinya.

Seringnya anak mendapati tindakan verbal abuse dari orang tua menyebabkan adanya suatu perubahan sikap yang pada akhirnya membentuk konsep diri negative pada anak. Dalam teori interaksi simbolik, konsep diri merupakan turunan dari teori interaksi simbolik, dimana terjadi pertukan simbolsimbol yang lama-kelamaan dapat membentuk konsep diri seseorang.

Pemikiran interaksi simbolik menjadi dasar untuk menjelaskan bagaimana makna atas simbolsimbol dapat menentukan pertukaran symbol yang terjadi dalam tindakan prosess komunikasi verbal abuse orang tua kepada anak. Maka, teori interaksi simbolik berasumsi bahwa remaja Kec. Kerumutan Kab. Pelalawan dapat mengerti berbagai hal dengan belajar dari pengalaman. Persepsi-persepsi yang 
dimiliki remaja tersebut akan diterjemahkan melalui simbol-simbol dalam interaksi. Dimana, sebuah makna dipelajari melalui interaksi mereka dengan orang lain (Kuswarno: 2009:114).

Konsep diri merupakan faktor yang sangat menentukan dalam komunikasi antarpribadi, karena setiap orang akan bertingkah laku sesuai dengan konsep dirinya. Suksesnya komunikasi antarpribadi banyak bergantung pada kualitas konsep diri seseorang. Menurut George Herbert Mead, cara manusia mengartikan dunia dan dirinya sendiri berkaitan erat dengan masyarakatnya. Hal tersebut dapat terlihat bahwa sebelum bertindak, seseorang akan mencoba untuk membayangkan dirinya dalam posisi orang lain. Sebagai manusia, kita tidak hanya melakukan persepsi terhadap orang lain, tetapi juga kita mempersepsi diri kita sendiri. Saat mempersepsi diri sendiri itu, diri kita menjadi subjek dan objek persepsi sekaligus.

Konsep diri remaja di Kec. Kerumutan Kab.Pelalawan dipengaruhi oleh significant others (orang yang memiliki arti dalam pembentukan konsep diri informan), yang terdiri dari dua jenis konsep diri, yaitu konsep diri positif dan konsep diri negatif. Dimana, konsep diri tersebut dilihat dari hal yang mereka lakukan dan interaksi dengan orang lain. Tindakan tersebut yang akan menentukan mereka termasuk remaja yang memiliki konsep diri positif atau konsep diri negatif.

Penelitian ini digolongkan pada konsep diri negative tipe Social Comparison yang menyebutkan bahwa dirinya memiliki pandangan sangat tergantung dari bagaimana ia memandang dirinya berkaitan dengan orang lain memandang dirinya. Hal tersebut ditunjukkan dari tindakan atau sikap remaja dimana ia dikatakan lamban dalam melakukan sesuatu oleh orang tuanya sehingga dikatakan "lelet" dengan nada kasar oleh orang tuanya. Sehingga ketika hendak melakukan sesuatu ia akan berpandangan bahwa dirinya memang seperti apa yang dikatakan oleh orang lain. Dengan kata lain pandangan mengenai dirinya sendiri benar-benar terlihat tidak teratur: dikarenakan konsep diri yang terbentuk di pengaruhi oleh orang lain.

Kemudian, konsep diri negatif lainnya bertipe Biased scanning yang menyatakan bahwa konsep diri seseorang bergantung pada bagaimana pandangannya terhadap lingkungan. Tipe ini menyebutkan bahwa seseorang melakukan sesuatu itu bukan saja untuk memenuhi keinginannya atau kebutuhannya, tetapi juga karena memang kondisi lingkungan terutama lingkungan keluarga yang membentuk sehingga ia cenderung merasa tidak disenangi oleh orang tuanya dan merasa tidak diperhatikan. Dengan demikian, ia bereaksi terlihat kurang adanya kehangatan dan keakraban dengan orang lain. Terkait dengan hasil penelitian komunikasi verbal abuse ini, tindakan tersebut dapat dilihat dari sikap yang dimiliki oleh remaja saat perilakunya suka mengganggu teman-temannya di kelas. Dan dirinya tidak senang dirumah walaupun dirinya malas kesekolah.

Hal ini menunjukkan bahwa mereka merasa tidak percaya diri dan tidak bisa menerima diri mereka apa adanya. Seperti yang diungkapkan oleh Calhoun dan Acocella bahwa pada konsep diri negatif, remaja tidak mengetahui kekuatan dan kelemahannya. Konsep diri mereka kerap tidak teratur untuk sementara waktu dan ini biasanya terjadi pada masa remaja yang merupakan masa transisi dari anak-anak menuju dewasa (Calhoun dan Acocella, 1995:72). Namun apapun itu, dalam kenyataannya tidak ada orang yang benar-benar sepenuhnya memiliki konsep diri positif atau negatif.

\section{Bentuk komunikasi verbal abuse orang tua pada remaja di Kecamatan Kerumutan Kabupaten Pelalawan:}

Bentuk komunikasi verbal abuse orang tua DD yaitu:

a. Membentak, yaitu memarahi dengan suara keras, antara lain :

1. menghardik, adalah mencaci dengan perkataan keras

2. menghakimi, adalah mengadili atau berlaku sebagai hakim

3. mengumpat, adalah mengeluarkan kata-kata kotor 
b. Memaki, yaitu mengucapkan kata-kata keji, tidak pantas, kurang baik dalam menyatakan kemarahan atau kejengkelan, antara lain :

1. mencela, yaitu menghina dengan terang-terangan

2. menyumpahi, adalah mengeluarkan kata-kata kotor untuk mengambil sumpah

c. Memberi julukan negatif atau melabel, yaitu memberi tanda identifikasi melalui bentuk katakata, antara lain, mengklasifikasi, penggolongan, pengelompokkan berdasarkan sesuatu yang sesuai dengan kelasnya. Ibu DD selalu memberikan lebel "lelet" kepada anaknya

Kekerasan yang dialami oleh anak dapat berdapak pada fisik maupun psikologis anak. Huberty (2012) menegaskan bahwa verbal abuse sangat berpengaruh pada anak terutama perkembangan psikologisnya, berikut dampak-dampak psikologis akibat kekerasan verbal pada anak. Beberapa hal yang dapat terlihat dari DD adalah:

1) Mengganggu perkembangan

Anak yang mendapatkan perlakuan salah secara terus menerus akan memiliki citra diri yang negatif. Hal tersebut mengakibatkan anak tidak mampu tumbuh sebagai pribadi yang penuh percaya diri. DD menjadi anak yang kurang percaya diri.

2) Konsep diri yang rendah

Anak yang sering mendapatkan perlakuan salah akan berpengaruh terhadap konsep dirinya. DD merasa dirinya jelek, tidak dicintai, tidak dikehendaki, muram, dan tidak bahagia, tidak mampu menyenangi aktifitas. DD menjadi kurang percaya diri, atau sebaliknya menjadi pemberontak.

3) Agresif

Bila anak tertekan karena terus menerus terperangkap dalam situasi yang kacau, penganiayaan, dan pengabaian, maka input hanya sampai ke batang otak. Sehingga sikap yang timbul hanya berdasarkan insting tanpa dipertimbangkan lebih dulu. Akibatnya anak berperilaku agresif.

4) Hubungan sosial

Pada anak-anak ini sering kurang dapat bergaul dengan teman sebayanya atau dengan orang-orang dewasa. Mereka mempunyai teman sedikit, dan suka menganggu orang dewasa, misalnya dengan melempari batu, atau perbuatan-perbuatan kriminal lainnnya.

5) Kepribadian sociopath atau antisocial personality disorder. Penyebab utama dari kepribadian ini adalah emotional child abuse yang dalam bentuk umumnya sering disebut juga dengan verbal abuse. Perilaku ini dapat terlihat dengan sering bolos, mencuri, bohong, bergaul dengan orang jahat, kejam pada binatang, dan prestasi sekolah yang buruk.

Akibat lain dalam jangka panjang yaitu anak yang mendapatkan kekerasan verbal akan melakukan hal yang sama dikelak kemudian hari terhadap anak-anaknya saat mereka menjadi orang tua. Karena esensinya anak-anak merupakan peniru ulung. Maka rantai kekerasan itu akan terus berlanjut, dan kekerasan ini menjadi sebuah budaya dalam masyarakat (Needlman,1998).

Menurut Soetjiningsih terdapat beberapa faktor yang mempengaruhi orang tua DD melakukan verbal abuse (Huraerah,2012), antara lain:

a) Faktor pengetahuan orang tua

Orang tua tidak mengetahui atau mengenal sedikit informasi mengenai kebutuhan perkembangan anak, misalnya usia anak belum memungkinkan untuk melakukan sesuatu tetapi karena sempitnya pengetahuan orang tua si anak dipaksa melakukan dan ketika memang belum mampu orang tua menjadi marah. Orang tua yang mempunyai harapan-harapan yang tidak realistik terhadap perilaku anak berperan memperbesar tindakan kekerasan pada anak. Serta kurangnya pengetahuan orang tua tentang pendidikan anak dan minimnya pengetahuan agama orang tua melatar belakangi kekerasan pada anak karena orang tua kurang berpendidikan. 
b) Faktor Pengalaman

Orang tua yang waktu kecilnya mendapat perlakuan salah merupakan situasi pencetus terjadinya kekerasan pada anak. Semua tindakan kepada anak-anak akan direkam dalam bawah sadar mereka dan akan dibawa sampai kepada masa dewasa, dan terus sepanjang hidupnya. Anak yang mendapat perlakuan kejam dari orang tuanya akan menjadi sangat agresif dan setelah menjadi orang tua akan berlaku kejam kepada anak-anaknya. Orang tua agresif melahirkan anak-anak yang agresif, yang pada gilirannya akan menjadi orang dewasa yang menjadi agresif. Gangguan mental (mental disorder) ada hubungannya dengan perlakuan buruk yang diterima manusia ketika dia masih kecil.

c) Faktor Keluarga

Faktor keluarga ini meliputi karakteristik anak, karakteristik orang tua dan keluarga. Karakteristik anak yang tidak diinginkan, lahir prematur, anak yang memiliki fisik berbeda (cacat), mental berbeda (retardasi mental), temperamen berbeda (sukar), tingkah laku berbeda (hiperaktif), dan anak angkat atau tiri berperan dalam orang tua melakukan kekerasan pada anaknya. Karakteristik orang tua dan keluarga yang juga turut berperan terhadap terjadinya kekerasan pada anak seperti; orang tua yang agresif dan impulsif, keluarga hanya dengan satu orang tua, orang tua yang dipaksa menikah saat belasan tahun sebelum siap secara emosional dan ekonomi, dan perkawinan dengan saling mencederai pasangannya dalam perselisihan.

d) Faktor ekonomi

Sebagian besar kekerasan dalam rumah tangga terjadi karena dipicu faktor kemiskinan dan tekanan hidup atau tekanan ekonomi. Pengangguran, PHK dan beban hidup lain kian memperparah kondisi. Faktor kemiskinan dan tekanan hidup yang semakin meningkat, disertai dengan kemarahan atau kekecewaan pada pasangan karena ketidakberdayaan dalam mengatasi masalah ekonomi menyebabkan orang tua mudah sekali meluapkan emosi, kemarahan, kekecewaan dan ketidakmampuannya kepada orang terdekatnya. Anak sebagai makhluk lemah, rentan, dan dianggap milik orang tua, anak menjadi paling mudah menjadi sasaran.

e) Faktor sosial budaya

Faktor sosial budaya ini meliputi nilai atau norma yang ada dimasyarakat, hubungan antar manusia, kemajuan zaman yaitu pendidikan, hiburan, olah raga, kesehatan, dan hukum. Norma sosial mempengaruhi tindakan orang tua melakukan verbal abuse karena pada masyarakat tidak ada kontrol sosial pada tindakan kekerasan anak-anak. Sedang nilai-nilai sosial disini adalah dalam artian hubungan anak dengan orang dewasa berlaku seperti hierarki sosial di masyarakat. Atasan tidak boleh dibantah. Orang tua tentu saja wajib ditaati dengan sendirinya. Dalam hierarki seperti itu anak-anak berada dalam anak tangga terbawah. Mereka tidak punya hak apa pun. Orang dewasa dapat berlaku apa pun kepada anak-anak.

f) Faktor lingkungan

Faktor lingkungan juga mempengaruhi tindakan kekerasan pada anak. Lingkungan hidup dapat meningkatkan beban terhadap perawatan anak. Dan juga munculnya masalah lingkungan yang mendadak turut berperan untuk timbulnnya kekerasan verbal.

Begitu pun pada informan SU, Bentuk komunikasi verbal abuse orang tua kepadanya yaitu Membentak (memarahi dengan suara keras), Memaki (mengucapkan kata-kata keji, tidak pantas, kurang baik dalam menyatakan kemarahan atau kejengkelan), Memberi julukan negatif atau melabel (memberi tanda identifikasi melalui bentuk kata-kata, antara lain, mengklasifikasi, penggolongan, pengelompokkan berdasarkan sesuatu yang sesuai dengan kelasnya). Ibu SU selalu memberikan lebel "bodoh" kepada anaknya. Mengecilkan dan melecehkan kemampuan anak (membuat jadi rendah keberadaan anak)

Kekerasan yang dialami oleh anak dapat berdapak pada fisik maupun psikologis anak. Huberty (2012) menegaskan bahwa verbal abuse sangat berpengaruh pada anak terutama perkembangan 
psikologisnya, berikut dampak-dampak psikologis akibat kekerasan verbal pada anak. Beberapa hal yang dapat terlihat dari SU adalah:

1. Mengganggu perkembangan (SU menjadi anak yang kurang percaya diri)

2. Konsep diri yang rendah

Anak yang sering mendapatkan perlakuan salah akan berpengaruh terhadap konsep dirinya. Anak akan merasa dirinya jelek, tidak dicintai, tidak dikehendaki, muram, dan tidak bahagia, tidak mampu menyenangi aktifitas. Anak biasanya menjadi kurang percaya diri, atau sebaliknya menjadi pemberontak.

3. Agresif

Komunikasi yang negatif mempengaruhi perkembangan otak anak. Anak yang selalu dalamkeadaan terancam sulit bisa berpikir panjang. Ia tidak bisa memecahkan masalah yang dihadapinya. Ini berkaitan dengan bagian otak yang bernama korteks, pusat logika. Bagian ini hanya bisa dijalankan kalau emosi anak dalam keadaan tenang. Bila anak tertekan karena terus menerus terperangkap dalam situasi yang kacau, penganiayaan, dan pengabaian, maka input hanya sampai ke batang otak. Sehingga sikap yang timbul hanya berdasarkan insting tanpa dipertimbangkan lebih dulu. Akibatnya anak berperilaku agresif.

6) Hubungan sosial

Pada anak-anak ini sering kurang dapat bergaul dengan teman sebayanya atau dengan orang-orang dewasa. Mereka mempunyai teman sedikit, dan suka menganggu orang dewasa, misalnya dengan melempari batu, atau perbuatan-perbuatan kriminal lainnnya.

7) Kepribadian sociopath atau antisocial personality disorder. Penyebab utama dari kepribadian ini adalah emotional child abuse yang dalam bentuk umumnya sering disebut juga dengan verbal abuse. Perilaku ini dapat terlihat dengan sering bolos, mencuri, bohong, bergaul dengan orang jahat, kejam pada binatang, dan prestasi sekolah yang buruk.

Faktor yang mempengaruhi orang tua SU melakukan verbal abuse (Huraerah,2012)

a. Faktor pengetahuan orang tua

Orang tua tidak mengetahui atau mengenal sedikit informasi mengenai kebutuhan perkembangan anak, misalnya usia anak belum memungkinkan untuk melakukan sesuatu tetapi karena sempitnya pengetahuan orang tua si anak dipaksa melakukan dan ketika memang belum mampu orang tua menjadi marah. Serta kurangnya pengetahuan orang tua tentang pendidikan anak dan minimnya pengetahuan agama orang tua melatar belakangi kekerasan pada anak karena orang tua kurang berpendidikan.

b. Faktor Pengalaman

Orang tua yang waktu kecilnya mendapat perlakuan salah merupakan situasi pencetus terjadinya kekerasan pada anak.

c. Faktor Keluarga

Faktor keluarga ini meliputi karakteristik anak, karakteristik orang tua dan keluarga. Karakteristik orang tua dan keluarga yang juga turut berperan terhadap terjadinya kekerasan pada anak seperti; orang tua yang agresif dan impulsif, keluarga hanya dengan satu orang tua, orang tua yang dipaksa menikah saat belasan tahun sebelum siap secara emosional dan ekonomi, dan perkawinan dengan saling mencederai pasangannya dalam perselisihan.

d. Faktor sosial budaya

Sedang nilai-nilai sosial disini adalah dalam artian hubungan anak dengan orang dewasa berlaku seperti hierarki sosial di masyarakat. Atasan tidak boleh dibantah. Orang tua tentu saja wajib ditaati dengan sendirinya. Dalam hierarki seperti itu anak-anak berada dalam anak tangga terbawah. Mereka tidak punya hak apa pun. Orang dewasa dapat berlaku apa pun kepada anak-anak.

e. Faktor lingkungan 
Faktor lingkungan juga mempengaruhi tindakan kekerasan pada anak. Lingkungan hidup dapat meningkatkan beban terhadap perawatan anak. Dan juga munculnya masalah lingkungan yang mendadak turut berperan untuk timbulnnya kekerasan verbal.

\section{Subjek AK}

Bentuk komunikasi verbal abuse orantua AK kepadanya yaitu Membentak (memarahi dengan suara keras), Memaki (mengucapkan kata-kata keji, tidak pantas, kurang baik dalam menyatakan kemarahan atau kejengkelan), Memberi julukan negatif atau melabel (memberi tanda identifikasi melalui bentuk kata-kata, antara lain, mengklasifikasi, penggolongan, pengelompokkan berdasarkan sesuatu yang sesuai dengan kelasnya). Ibu AK selalu memberikan lebel "bodoh" kepada anaknya. Mengecilkan dan melecehkan kemampuan anak (membuat jadi rendah keberadaan anak)

Kekerasan yang dialami oleh anak dapat berdapak pada fisik maupun psikologis anak. Huberty (2012) menegaskan bahwa verbal abuse sangat berpengaruh pada anak terutama perkembangan psikologisnya, berikut dampak-dampak psikologis akibat kekerasan verbal pada anak. Beberapa hal yang dapat terlihat dari AK adalah:

1. Mengganggu perkembangan (AK menjadi anak yang kurang percaya diri)

2. Konsep diri yang rendah

Anak yang sering mendapatkan perlakuan salah akan berpengaruh terhadap konsep dirinya. Anak akan merasa dirinya jelek, tidak dicintai, tidak dikehendaki, muram, dan tidak bahagia, tidak mampu menyenangi aktifitas. Anak biasanya menjadi kurang percaya diri, atau sebaliknya menjadi pemberontak.

3. Agresif

Komunikasi yang negatif mempengaruhi perkembangan otak anak. Anak yang selalu dalamkeadaan terancam sulit bisa berpikir panjang. Ia tidak bisa memecahkan masalah yang dihadapinya. Ini berkaitan dengan bagian otak yang bernama korteks, pusat logika. Bagian ini hanya bisa dijalankan kalau emosi anak dalam keadaan tenang. Bila anak tertekan karena terus menerus terperangkap dalam situasi yang kacau, penganiayaan, dan pengabaian, maka input hanya sampai ke batang otak. Sehingga sikap yang timbul hanya berdasarkan insting tanpa dipertimbangkan lebih dulu. Akibatnya anak berperilaku agresif.

4. Hubungan sosial

Pada anak-anak ini sering kurang dapat bergaul dengan teman sebayanya atau dengan orang-orang dewasa. Mereka mempunyai teman sedikit, dan suka menganggu orang dewasa, misalnya dengan melempari batu, atau perbuatan-perbuatan kriminal lainnnya.

5. Kepribadian sociopath atau antisocial personality disorder

Penyebab utama dari kepribadian ini adalah emotional child abuse yang dalam bentuk umumnya sering disebut juga dengan verbal abuse. Perilaku ini dapat terlihat dengan sering bolos, mencuri, bohong, bergaul dengan orang jahat, kejam pada binatang, dan prestasi sekolah yang buruk.

faktor yang mempengaruhi orang tua AK melakukan verbal abuse (Huraerah,2012)

a. Faktor pengetahuan orang tua

Orang tua tidak mengetahui atau mengenal sedikit informasi mengenai kebutuhan perkembangan anak, misalnya usia anak belum memungkinkan untuk melakukan sesuatu tetapi karena sempitnya pengetahuan orang tua si anak dipaksa melakukan dan ketika memang belum mampu orang tua menjadi marah. Serta kurangnya pengetahuan orang tua tentang pendidikan anak dan minimnya pengetahuan agama orang tua melatar belakangi kekerasan pada anak karena orang tua kurang berpendidikan. 
b. Faktor Pengalaman

Orang tua yang waktu kecilnya mendapat perlakuan salah merupakan situasi pencetus terjadinya kekerasan pada anak.

c. Faktor Keluarga

Faktor keluarga ini meliputi karakteristik anak, karakteristik orang tua dan keluarga. Karakteristik orang tua dan keluarga yang juga turut berperan terhadap terjadinya kekerasan pada anak seperti; orang tua yang agresif dan impulsif, keluarga hanya dengan satu orang tua, orang tua yang dipaksa menikah saat belasan tahun sebelum siap secara emosional dan ekonomi, dan perkawinan dengan saling mencederai pasangannya dalam perselisihan.

d. Faktor ekonomi

Sebagian besar kekerasan dalam rumah tangga terjadi karena dipicu faktor kemiskinan dan tekanan hidup atau tekanan ekonomi. Pengangguran, PHK dan beban hidup lain kian memperparah kondisi. Faktor kemiskinan dan tekanan hidup yang semakin meningkat, disertai dengan kemarahan atau kekecewaan pada pasangan karena ketidakberdayaan dalam mengatasi masalah ekonomi menyebabkan orang tua mudah sekali meluapkan emosi, kemarahan, kekecewaan dan ketidakmampuannya kepada orang terdekatnya. Anak sebagai makhluk lemah, rentan, dan dianggap milik orang tua, anak menjadi paling mudah menjadi sasaran.

e. Faktor sosial budaya

Sedang nilai-nilai sosial disini adalah dalam artian hubungan anak dengan orang dewasa berlaku seperti hierarki sosial di masyarakat. Atasan tidak boleh dibantah. Orang tua tentu saja wajib ditaati dengan sendirinya. Dalam hierarki seperti itu anak-anak berada dalam anak tangga terbawah. Mereka tidak punya hak apa pun. Orang dewasa dapat berlaku apa pun kepada anakanak.

f. Faktor lingkungan

Faktor lingkungan juga mempengaruhi tindakan kekerasan pada anak. Lingkungan hidup dapat meningkatkan beban terhadap perawatan anak. Dan juga munculnya masalah lingkungan yang mendadak turut berperan untuk timbulnnya kekerasan verbal.

\section{KESIMPULAN}

Berdasarkan hasil penelitian yang dilakukan dengan wawancara dan observasi yang dilakukan oleh peneliti mengenai Komunikasi Verbal Abuse Orang Tua pada Konsep Diri Remaja di Kec. Kerumutan Kab.Pelalawan, dapat diambil kesimpulan sebagai berikut:

a. Konsep diri yang dimiliki remaja di Kec. Kerumutan Kab.Pelalawan dipengaruhi oleh significant others. Dimana, konsep diri remaja di Kec. Kerumutan Kab.Pelalawan adalah konsep diri bertipe negative yakni tipe social comparasion dan Biased scannin. Konsep diri negatif tipe social comparision adalah berpandangan bahwa dirinya memang seperti apa yang dikatakan oleh orang lain sehingga pandangan mengenai dirinya sendiri benar-benar terlihat tidak teratur dikarenakan konsep diri yang terbentuk di pengaruhi oleh orang lain. Sedangkan konsep diri negatif tipe Biased scannin. Ditunjukkan dari sikap remaja yang ia cenderung merasa tidak disenangi oleh orang tuanya dan merasa tidak diperhatikan. Reflected Appraisal menyatakan bahwa konsep diri seseorang akan terbentuk jika ia mendapatkan penghargaan dari orang lain. Dimana, pemberi penghargaan dan besarnya penghargaan yang diterima seseorang tersebut akan menentukan derajat konsep diri yang terbentuk. Penghargaan dari orang-orang yang dianggap penting bagi seseorang (significant others seperti: orang tua, teman, saudara, dan sebagainya) juga memberikan pengaruh yang sangat besar terhadap pengembangan konsep diri. 
b. Interaksi simbolik menjadi dasar bagaimana makna atas simbol-simbol dapat menentukan tindakan remaja dalam proses interaksi yang berlangsung dengan orang lain. Maka, teori interaksi simbolik berasumsi bahwa remaja di Kec. Kerumutan Kab. Pelalawan yang mana persepsi-persepsi yang dimiliki remaja tersebut akan diterjemahkan melalui simbol-simbol dalam interaksi. Karena di dalam proses interaksi simbolik yang terjadi dari pertukan simbol-simbol yang lama-kelamaan dapat membentuk konsep diri seseorang.

\section{SARAN}

Adapun faktor penghambat dalam Budaya organisasi Dinas Penanamam Modal dan Pelayanan Terpadu satu Pintu Provinsi Riau yaitu Lamanya penerbitan izin yang dilakuakan pada Dinas Penanamam Modal dan Pelayanan Terpadu Satu Pintu Provinsi Riau dan Lemahnya pemberian sanksi Pada Dinas Penanamam Modal dan Pelayanan Terpadu Satu Pintu Provinsi Riau.Ada beberapa Saran dari penulis dalam penelitian ini, yaitu :

1. Hendaknya Pegawai Dinas Penanaman Modal dan Pelayanan Terpadu Satu Pintu Provinsi Riau dalam melaksanakan tugas nya mampu dengan menguasaai segala prosedur pelayanan yang telah ditetapkan agar tidak terjadinya keterlambatan dalam melakukan penerbitan perizinan.

2. Adanya pemberian reward kepada Pegawai agar pegawai yang mempunyai kinerja yang baik akan merasa diperhatikan dan dipersamakan dengan pegawai yang butuk kinerjanya. dan agar pegawai lebih semangat dalam melaksanaan pekerjaan. Hal ini akan mempengaruhi dalam pencapaian visi dan misi organisasi.

3. Pegawai Dinas Penanamam Modal dan pelayanan Terpadu Satu Pintu Provinsi Riau lebih menpererat tali persaudaraan antara seluruh pegawai dilingkungan Dinas Penanamam Modal dan Pelayanan Terpadu Satu Pintu Provinsi Riau untuk meningkatkan Team work dan pembagian pekerjaan secara professional kepada pegawai.

4. Bagi Pegawai Dinas Penanamam modal dan Pelayanan Terpadu Satu Pintu Provinsi Riau hendaknya lebih meperhatikan penerapan budaya organisasi yang pada lingkungan Dinas Penanamam Modal dan Pelayanan Terpadu Satu Pintu Provinsi Riau.

\section{DAFTAR PUSTAKA}

[1]. Cervone, Daniel, Lawrence A. Pervin dan Oliver P. John, 2012. Psikologi Kepribadian: Teori dan Penelitian(Edisi Kesembilan). Jakarta: Kencana Prenada Media Group

[2]. Charles, Zastrow, \& Bowker, Lee. 1998, Social Problems: Issues and Solutions, Chicago: NelsonHall

[3]. Desmita. 2005. Psikologi Perkembangan.Bandung: Rosda Karya

[4]. Devito, Joseph A. 1997. Komunikasi Antarmanusia. Edisi kelima. Jakarta : Profesional Books

[5]. Hardjana, A. M. (2003). Komunikasi intrapersonal dan interpersonal. Yogyakarta: Kanisius

[6]. Huberty, Thomas J. 2012. Anxiety And Depression In Children And Adolescents. New York: Springer. 
[7]. Hurlock, Elizabeth B. 1992.Psikologi Perkembangan Suatu pendekatan rentang kehidupan. Edisi kelima. Erlangga

[8]. Infante, D.A., \& Wigley, C.J. 1987. "Verbal Aggressiveness: An Interpersonal Model and Measure". Communication Monographs, 53(1), p. 61-69

[9]. Jennifer Loh, Flora Calleja, and Simon Lloyd D. Restubog, 2015. Words That Hurt: A Qualitative Study of Parental Verbal Abuse in the Philippines. Journal of Interpersonal Violence26(11) 22442263

[10]. Knapp, M.L., Stafford, L., \& Daly, J.A. 1986. "Regrettable Messages: Things People Wish They Haven't Said". Journal of Communication, 36,p. 40-58

[11]. Kuswarno, Engkus,2009. Metodologi Penelitian Komunikasi Fenomenologi: Konsepsi, Pedoman, dan Contoh Penelitian Fenomena Pengemis Kota Bandung. Bandung: Widya Padjadjaran.

[12]. West, Richard dan Lynn H. Turner, 2009. Pengantar Teori Komunikasi Analisis dan Aplikasi (Edisi 3). Jakarta: Salemba Humanika. 